\title{
Kekerasan pada Setiap Tahap Penempatan TKI Asal Propinsi Sumatera Barat Tahun 2006
}

\author{
Helfi Agustin*
}

\begin{abstract}
Abstrak
Peningkatan jumlah tenaga kerja Indonesia yang diberangkatkan keluar negeri seiring dengan kebijakan nasional diikuti oleh peningkatan berbagai masalah yang mengarah pada pelanggaran hak azasi manusia. Penelitian ini bertujuan mengetahui berbagai kekerasan yang menyertai setiap tahap penempatan tenaga kerja Indonesia dan dampaknya terhadap kesehatan. Penelitian ini menggunakan metoda kualitatif dengan metode pengumpulan data wawancara mendalam dan metoda analisis tema. Penelitian diadakan di Propinsi Sumatera Barat, pada bulan April-Mei 2006. Hasil penelitian menemukan semua TKI berangkat pada usia muda. TKI dengan tingkat pendidikan/ akses informasi terbatas mudah terjebak dalam pemberangkatan ilegal. Semua TKI mengalami beberapa bentuk kekerasan secara bersamaan dan berulang Besar dan besar dampak kekerasan bergradasi menurut jenis kelamin. TKI legal mengalami eksploitasi karena peraturan dan mekanisme penempatan yang belum melindungi hak azasi manusia. Kekerasan tidak hanya terjadi ketika TKI bekerja di luar negeri, tetapi sejak pra pemberangkatan sampai saat pemulangan. TKI ilegal menghadapi resiko pelanggaran hak azasi manusia yang lebih besar dan mengalami kekerasan dengan gradasi dampak yang lebih berat. Untuk menghentikan pemberangkatan ilegal, disarankan pada Dinas Tenaga Kerja Propinsi Sumatera Barat untuk meningkatkan kesadaran masyarakat tentang aspek migrasi internasional melalui informasi publik. Kepada Depnakertrans RI diharapkan dapat merevisi peraturan dan melakukan upaya diplomasi yang berorientasi pada perlindungan hak azasi manusia dengan merujuk pada kesepakatan internasional.
\end{abstract}

Kata kunci : Kekerasan, kualitatif, TKI, Sumatera Barat

\begin{abstract}
Indonesian government has determined a policy of employment placement as national program. With the raising number of Indonesian migrant workers, the related problems are also raising. The research is qualitative research and data were taken by in-depth interview method. The aim of this study is to know the form of abuse of Indonesian migrant workers in all placements and its health impact. Thematic analysis was used in this study. The study was held in West Sumatera Province in April -May 2006. The research finds that all of Indonesian Migrant Workers left the country at young ages. Those workers with low education level or had limited access to information were easily trapped in illegal departure. The form and magnitude of abuse were gradual according to sex. All Indonesian migrant workers experienced various kind of abuses simultaneously and repeatedly. Illegal Indonesian migrant workers are exploited because of the rule and mechanism of placement do not comply to human rights protection. Abuse does not only happen when Indonesian migrant workers are abroad but also before leaving and after coming home. Illegal Indonesian migrant workers faced higher risk of human rights violation and undergo abuse with greater impact. Government should improve citizen awareness to prevent abuse through elimination of illegal departure by giving information to wider public, and to have strong political commitment to revise rules related to migrant workers as well as to foster diplomatic efforts towards human right protection of Indonesian migrant workers.
\end{abstract}

Key words : Violence, qualitative, Indonesian migrant workers, West Sumatera 
Menurut WHO, sehat adalah keadaan yang sempurna fisik dan mental serta sejahtera secara sosial, tidak hanya bebas dari penyakit atau kecacatan. Defenisi tersebut telah mengubah pola berfikir lama yang membatasi sakit pada masalah biomedis dan kelainan patologi dengan menambahkan dimensi kesejahteraan mental dan sosial. Deklarasi Alma-Ata (1978) menyatakan pencapaian kesehatan membutuhkan sektor ekonomi dan sosial. ${ }^{1}$ Undang-Undang Hak Azasi Manusia Internasional (Universal Declaration of Human Rights) menetapkan bahwa setiap orang berhak atas keselamatan pribadi. Setiap individu harus terbebas dari siksaan dan perlakuan kejam yang tidak manusiawi dan merendahkan dalam bentuk apapun. Dengan demikian, kekerasan merupakan pelanggaran terhadap Hak Azasi Manusia yang terkait dengan kesehatan karena keduanya bertujuan meningkatkan kesejahteraan manusia. ${ }^{2}$ Penelitian ini terfokus pada konsep Mann ${ }^{2}$ tentang hubungan antara kesehatan masyarakat dan hak azasi manusia yang didasarkan pada pemahaman bahwa pelanggaran hak azasi manusia berdampak terhadap kesehatan.

Kekerasan bukan saja melangar hak azazi manusia tetapi juga berdampak buruk terhadap kesehatan. Oleh sebab itu, pada tahun 1996, pada pertemuan kesehatan dunia (World Health Assembly) yang dihadiri oleh 190 negara menyetujui resolusi yang menyatakan kekerasan menjadi prioritas kesehatan dunia. ${ }^{3}$ Resolusi WHO tersebut mengarah pada pengembangan rencana upaya pencegahan kekerasan berbasis pendekatan kesehatan masyarakat yang menekankan upaya pencegahan pada tingkat primer sebelum peristiwa tersebut terjadi. Kesehatan masyarakat berperan pada upaya advokasi meningkatkan perhatian dan kesadaran masyarakat dan berbagai pihak terkait bahwa kekerasan adalah sebuah realita yang dapat dicegah. ${ }^{4}$

Di Propinsi Sumatera Barat, pemerintah daerah berupaya meningkatkan jumlah tenaga kerja Indonesia ke luar. Upaya yang memperlihatkan kecenderungan meningkat dari tahun ke tahun itu ternyata berdampak pada peningkatan kasus kekerasan. Hal tersebut menggugah beberapa tokoh Minang yang bermukim di Malaysia untuk menghimbau penghentian pengiriman tenaga kerja terutama wanita asal Minang ke Malaysia. Hal tersebut telah mengudang reaksi pro dan kontra di dalam masyarakat. ${ }^{5}$ Data resmi tindak kekerasan terhadap tenaga kerja Indonesia asal Propinsi Sumatera Barat belum ada, tetapi berdasarkan analisis Sekretariat Konsorsium Pembela Buruh Migran (Kopbumi), ternyata banyak kasus kekerasan tenaga kerja Indonesia yang tidak tercatat. Hal tersebut kemungkinan disebabkan oleh pola spesifik migrasi masyarakat Minang yang disebut merantau dan Propinsi Sumatera Barat yang merupakan wilayah transit bagi tenaga kerja Indonesia illegal. Berbagai tindakan kekerasan yang terjadi tidak terpub- likasi dan tersimpan dalam harmoni, untuk mencegh kepanikan dan penurunan minat untuk bekerja diluar negeri. Penelitian ini bertujuan untuk mengungkapkan kasus kekerasan tersebut berikut berbagai faktor yang mempengaruhinya secara kualitatif.

\section{Metode}

Penelitian yang dilakukan di Propinsi Sumatera Barat pada periode April-Mei 2006 ini adalah penelitian kualitatif. Metoda pengumpulan data adalah wawancara mendalam yang digunakan untuk menggali berbagai informasi yang diteliti dengan informan adalah tenaga kerja Indonesia. Untuk mendapat gambaran yang menyeluruh tentang TKI, informasi sistem penempatan TKI dikumpulkan dari staf PJTKI, Ketua Apjati, Kasie Penempatan Tenaga Kerja Luar Negeri Dinas Tenaga Kerja dan Transmigrasi Propinsi Sumatera Barat serta anggota LSM Konsorsium Pembela Buruh Migran (Kopbumi). Penelitian ini menggunakan metoda analisis tematik dengan cara menemukan karakteristik pesan yang dilakukan secara objektif dan sistematis.

\section{Hasil \\ Karakteristik}

Penelitian ini menemukan bahwa semua informan TKI berusia muda dengan umur berkisar 17-33 tahun. Informan perempuan menyatakan mengalami kekerasan fisik langsung seperti pukulan, upaya perkosaan, dan larangan makan. Kekerasan itu lebih berat daripada kekerasan yang dialami oleh informan laki-laki umumnya hanya mengalami kekerasan ekonomi. Kekerasan pada TKI laki-laki antara lain adalah penahanan, pemotongan atau penghentian pembayaran gaji dan kekerasan psikologis seperti hinaan, bentakan dan makian.

Pendidikan calon TKI yang rendah menempatkan calo pada peranan yang penting dalam memenuhi kebutuhan pendidikan untuk bekerja di luar negeri. Semua informan TKI yang berpendidikan rendah menyatakan bahwa mereka mendapatkan informasi dari calo. Tingkat pendidikan dan akses informasi yang rendah ternyata merupakan peluang bagi para calo untuk menyediakan jasa pemberangkatan. Para calo umumnya adalah orang yang dikenali oleh informan TKI, sehingga hubungan TKI-calo terjadi karena kedekatan sosial.

Informan TKI ilegal tidak pernah mendapatkan keterampilan sebelum berangkat ke luar negeri. Mereka umumnya bekerja di sektor informal yang menangani berbagai pekerjaan yang tergolong berbahaya, sulit dan kotor (dangerous, difficult dan dirty) (3D). Sebaliknya, TKI legal yang mendapatkan pelatihan sebelum berangkat menghadapi masalah ketidaksesuaian materi pelatihan. Misalnya, materi bahasa yang dipelajari pada pelatihan berbeda dengan bahasa yang digunakan di negara tujuan bekerja. Hal ini mengisyaratkan bahwa 
Tabel 1. Karakteristik Informan TKI

\begin{tabular}{|c|c|c|c|c|c|c|}
\hline Karakteristik & TKI 1 & TKI 2 & TKI 3 & TKI 4 & TKI 5 & TKI 6 \\
\hline $\begin{array}{l}\text { Umur } \\
\text { Jenis Kelamin }\end{array}$ & $\begin{array}{l}21 \text { th } \\
\text { pria }\end{array}$ & $\begin{array}{l}18 \text { th } \\
\text { wanita }\end{array}$ & $\begin{array}{l}17 \text { th } \\
\text { wanita }\end{array}$ & $\begin{array}{l}26 \text { th } \\
\text { pria }\end{array}$ & $\begin{array}{l}20 \text { th } \\
\text { pria }\end{array}$ & $\begin{array}{l}33 \text { th } \\
\text { pria }\end{array}$ \\
\hline Pendidikan & SLTP & Tak sekolah & SLTP & SLTA & STM & D3 \\
\hline Pekerjaan sebelumnya & Buruh & PRT & Buruh & Kantor pos & Pelajar & Fitness-spa \\
\hline Sumber Informasi ttg pekerjaan & Tekong & Calo & Calo & Pelanggan pos & Kepala sekolah & Atasan \\
\hline Status TKI & Ilegal & Ilegal & Ilegal & Legal & Legal & Legal \\
\hline Jenis Kekerasan & $\begin{array}{l}\text { Ekonomi, } \\
\text { human } \\
\text { trafficking }\end{array}$ & $\begin{array}{l}\text { Fisik, } \\
\text { seksual }\end{array}$ & Fisik, psikis & Ekonomi, psikis & $\begin{array}{l}\text { Ekonomi, fisik, } \\
\text { psikis }\end{array}$ & $\begin{array}{l}\text { Ekonomi, fisik } \\
\text { psikis, seksual }\end{array}$ \\
\hline
\end{tabular}

pelatihan pada TKI legal belum efektif dan cenderung hanya bersifat formalitas.

\section{Kekerasan}

Kekerasan terhadap TKI yang secara sinambung, terdiri dari berbagai jenis dengan gradasi yang bervariasi. Jenis kekerasan tersebut meliputi kekerasan ekonomi, kekerasan fisik dan kekerasan psikologi. Berbagai jenis kekerasan tersebut terjadi secara sinambung disepanjang perjalanan TKI mulai pada tahap sebelum pemberangkatan, pada periode bekerja, sampai dengan periode kembali ke Indonesia.

\section{Tahap Pra Pemberangkatan}

Dengan modus peminjaman uang untuk proses pemberangkatan, para TKI tersebut terjerat hutang selama berbulan-bulan. Khusus untuk TKI legal, ditemui kasus peningkatan pungutan biaya pemberangkatan yang melebihi ketetapan dan kasus eksploitasi tenaga CTKI di tempat penampungan. Hal tersebut antara lain dilakukan dengan alasan menghemat biaya pengelolaan perusahaan melalui sistem kurvei/sistem piket pekerjaan cleaning service, memasak untuk seluruh anggota penampungan dan karyawan perusahaan. Penelitian ini menemukan kekerasan fisik pada fase pra pemberangkatan di tempat pelatihan yang dilaksanakan secara semi militer. Meskipun informan menerima perlakuan tersebut sebagai bagian dari pelatihan disiplin, tetapi perlakuan yang membahayakan fisik seharusnya tidak dilegitimasi sebagai bagian dari program pelatihan.

"Ada...orang Jepangnya waktu itu, keras dia...apabila kita salah tu kita langsung kena tinju, waktu lagi praktek.” (infk-5)

Calon TKI 4 yang akan bekerja di Taiwan wajib mengikuti pelatihan selama 3 bulan. Menurut informan TKI 4, dia dan 50 orang calon TKI lain tidur di dalam satu barak penampungan yang berukuran $6 \times 10$ meter $^{2}$. Hal ini terjadi karena pengawasan Depnaker terhadap calon TKI di penampungan yang sangat lemah.

Sesuai dengan temuan ini, Human Right Watch menemukan bahwa hampir semua pekerja yang di- wawancarai tinggal di pusat pelatihan pada saat perekrutan lebih dari 3 bulan.

\section{Di Tempat Kerja \\ Kekerasan Ekonomi}

Seluruh informan yang diwawancarai menyatakan pernah mengalami kekerasan ekonomi yang terkait dengan gajian/upah mereka. Kekerasan ekonomi tersebut bervariasi dari yang paling ringan sampai yang berat berupa tidak diberi uang lembur, tidak menerima gaji secara penuh, tidak menerima gaji selama satu tahun, sampai tidak menerima gaji sama sekali. Lebih lanjut, para informan tersebut mangalami kesulitan mengklaim gaji mereka ketika mereka dideportasi ke Indonesia.

"sesampainya disana menganggur tanpa gaji...selama 1 tahun" (infk-6)

"kami dipaksa lembur-lembur terus, untuk tenaga kerja lain tidak. Khusus untuk orang Indonesia lembur karena orang asli pakai upah lembur" (infk-5).

\section{Kekerasan Fisik}

Penelitian ini menemukan beberapa informan mengalami kekerasan fisik dalam bentuk bekerja yang panjang dan penggunaan waktu libur sebagai jam kerja (TKI 2, 3, 5 dan 6). Juga ditemukan informan yang dilarang makan dan dipaksa bekerja walau dalam keadaan sakit. Informan TKI 5 menceritakan pengalamannya:

"Orang Jepang tu juga ndak peduli jika kita sakit atau apa. Pernah saya mengalami sakit kepala dan muntah-muntah...dibiarkan saja. Paling dikasih obat terus disuruh kerja lagi” (infk-5)

Menurut informan LSM, peran kedutaan dalam memberikan jaminan terlindunginya hak azasi TKI di luar negeri sangat penting. Hal tersebut dapat dilakukan dengan menuangkannya dalam MOU dan melakukan langkah-langkah diplomatik untuk menentukan standar perlindungan TKI yang sesuai dengan hak-hak buruh migran yang dinyatakan dalam konvensi ILO tahun 1990. Tetapi hal tersebut tampaknya belum dilakukan secara optimal, terbukti dengan ditemukannya barbagai bentuk kekerasan tersebut. 


\section{Kekerasan Psikologis}

Beberapa tenaga kerja mengalami kekerasan psikologik berupa hinaan, cacian, dan bentakan dengan kata-kata yang kasar dan merendahkan. Kekerasan psikologis yang dialami TKI tersebut bervariasi, seperti direndahkan dengan mengatakan tenaga kerja Indonesia bodoh, lamban dan malas atau hinaan dengan sebutan nama binatang seperti monyet atau keledai.

"Bos itu suka bilang .." baka" (goblok/bodoh)" (in$f k-5)$

"Sifatnya yang kasar itu membuatnya mudah menyumpah serapah kita...seperti istilah ... khamar!(keledai)"...(infk-6)

\section{Kekerasan Seksual}

Penelitian ini menemukan informan perempuan (TKW) yang mengalami ancaman perkosaan dan pelecehan seksual dari majikan laki-laki.

"Majikan laki-laki berusaha memperkosa"(infk-2)

\section{Tahap Pemulangan}

Kekerasan Ekonomi

Penelitian ini tidak menemui keluhan tentang berbagai kasus yang merugikan informan ketika pulang melalui bandara tersebut. Informan TKI 1 menyatakan terjebak perdagangan manusia pada saat dipulangkan dari Malaysia ke Indonesia. Dia diperdagangkan dan dieksploitasi dalam kondisi kerja paksa oleh preman yang berada di tempat pembuangan TKI ilegal di Malaysia saat dipulangkan ke Indonesia. Penggunaan taktik yang memaksa, tipu daya, jebakan kerja paksa tersebut termasuk dalam definisi perdagangan manusia.

"Kami tidak mempunyai uang sepeserpun. Kami bermaksud mencari kerja, tapi kami disana kan ditampung, istilahnya... dikasih makan oleh orang di kampung itu. Jadi ada orang disana yang memang bekerja mencari orang. Dibeli dari orang yang menampung kita tu. Sama dengan kita membeli barang, susah juga, sudah pulang dari Malaysia, pulang ke Indonesia, negara kita, bukannya enak, malah tambah payah.. Habis gimana ....mau apa...nggak ada uang...jadi kita nurut aja sama orang tu... mau nggak mau”. (infk-1)

\section{Kekerasan Fisik}

Sampai sedemikian jauh belum ada catatan tentang suntik pana yang menurut masyarakat merupakan suntikan yang mengakibatkan kehilangan ingatan dan bingung. Penelitian ini menemukan rumor suntik "pana" pada TKI ilegal yang pulang dari Malaysia. Walaupun sulit dipercaya, hal tersebut juga ditemukan pada TKI di Daerah Tingkat II lainnya di Propinsi Sumatera Barat. Menurut mereka, suntik pana diberikan oleh petugas Malaysia pada TKI ilegal, tetapi tidak semua TKI ilegal mendapatkannya.

\section{Kekerasan Psikologis}

Kekerasan psikologis saat pemulangan yang ditemukan dalam penelitian ini adalah dalam bentuk penahanan paspor oleh majikan. Informan TKI 6 ditahan untuk terus bekerja walau sudah tidak betah bekerja karena berbagai kecurangan majikan. Dia tak berdaya, karena paspor nya ditahan oleh majikan, sehingga terpaksa terus bekerja.

\section{Dampak terhadap Kesehatan \\ Kesehatan Pisik}

Akibat kekerasan fisik yang dialami oleh informan dalam penelitian ini adalah luka dan penurunan kondisi fisik. Salah satu informan TKI ilegal pernah mengalami luka yang cukup serius akibat pukulan majikan sehingga dirawat di rumah sakit dan akhirnya dipulangkan ke Indonesia. Salah satu informan TKI legal mengalami kekerasan fisik berupa pemukulan oleh pelatih pada saat latihan yang hingga meninggalkan bekas memar. Namun, pada saat di tempat kerja maupun saat pulang semua informan TKI legal tidak mengalami kekerasan fisik, sehingga tidak mengalami dampak fisik seperti luka dan memar. Akan tetapi salah satu informan beberapa kali mengalami sakit di tempat kerja sebagai akibat beban kerja yang berat dan waktu istirahat yang kurang.

\section{Kesehatan Psikologis}

Semua informan TKI ilegal menyatakan trauma dan tidak ingin kembali bekerja di luar negeri. Peneliti melihat kecenderungan sikap menarik diri dari lingkungan sosial dan berbicara seperlunya pada informan TKI2. Informan mengungkapkan rasa kecewa dan penyesalan akibat berbagai kerugian-kerugian ekonomi yang berhubungan dengan masalah gaji/upah yang mereka alami. Menurut keluarga, informan TKI 4 merasakan kekecewaan mendalam yang menyebabkan perubahan perilaku menjadi lebih banyak merokok dan meminum minuman keras, juga terlihat perasaan tidak berdaya. Beberapa informan lain menyatakan mengalami stress/ tekanan psikis akibat teriakan dan makian majikan. Salah satu informan TKI ilegal mengalami depresi berat, tetapi berkembang rumor di dalam masyarakat bawa TKI tersebut mengalami depresi sebagai akibat suntik pana yang dilakukan pihak petugas di Malaysia.

\section{Pembahasan \\ Karakteristik \\ Umur}

Hasil tersebut tidak jauh berbeda dengan penelitian TKI yang dilakukan di propinsi lain bahwa migrasi ke negara lain didominasi oleh tenaga kerja usia muda.6-8 Temuan ini dikuatkan dengan hukum migrasi Ravenstein (1885) yang mengatakan migran biasanya terdiri dari golongan usia muda. ${ }^{9}$ Hal tersebut tampaknya tidak ter- 
lepas dari kebijaksanaan pemerintah melalui UU RI No. 39 tahun 2004 tentang penempatan dan perlindungan tenaga kerja luar negeri yang mensyaratkan usia minimum untuk adalah 18 tahun untuk sektor formal dan dan 21 tahun bagi perempuan untuk sektor informal. Penemuan TKI yang pada saat berangkat berumur kurang 21 tahun dan kasus penuaan umur pada informan mengindikasikan adanya cara yang ilegal pada pemberangkatan TKI. Seperti yang diungkapkan oleh informan LSM, modus penggantian identitas umur, alamat dan ijazah banyak dilakukan oleh calo. Hal tersebut terutama dilakukan terhadap TKI legal sektor non formal dan TKI ilegal. Peningkatan risiko kekerasan di tempat kerja meningkat pada pekerja muda diduga sebagai akibat keberanian mencari tantangan dan mengambil resiko. Selain itu, hal tersebut dapat disebabkan oleh ketidakmatangan, ketidaktahuan dan keterbatasan informasi sehingga mereka mudah terjebak oleh modus penipuan yang dilakukan oleh calo.

\section{Jenis Kelamin}

Dari data Dinas Tenaga Kerja dan Transmigrasi Propinsi Sumatera Barat, pada periode 1998 - 2005, terlihat rasio antara TKI wanita dan TKI laki-laki yang mencolok (7.396 : 1.906). Tampaknya, kecenderungan peningkatan tenaga kerja wanita yang terjadi di Indonesia juga telah melanda Propinsi Sumatera Barat. Hal tersebut, tampaknya telah memunculkan berbagai persoalan yang berhubungan dengan status mereka sebagai perempuan. Oleh sebab itu, para tokoh Minang di Malaysia mengusulkan penghentian pengiriman tenaga kerja wanita Minang ke Malaysia. Sikap tersebut sesuai dengan prinsip dasar masyarakat Minangkabau yang komunal bezit dan keluarga laki-laki yang bertangungjawab melindungi (mamak rumah).

Penyebab utama kekerasan pada perempuan adalah kesenjangan relasi gender yang menyebabkan perempuan tersubordinasikan oleh masyarakat dan menempatkan laki-laki lebih utama daripada perempuan. ${ }^{10}$ Pada budaya Minangkabau kesenjangan relasi gender tersebut tidak kentara, tetapi di tempat kerja kesenjangan tersebut terlihat lebih lebar. Tidak dipungkiri bahwa kebanyakan kepercayaan, norma, nilai institusi sosial menganut budaya patriaki yang melegitimasi kekerasan terhadap perempuan. Temuan penelitian ini sesuai temuan ILO bahwa pekerja perempuan lebih besrisiko mengalami kekerasan daripada pekerja laki-laki. ${ }^{11}$

\section{Pendidikan}

Tenaga kerja migran Indonesia umumnya berpendidikan rendah. $8,12,13$ Penelitian ini menemukan bahwa semua informan TKI ilegal berpendidikan SLTP ke bawah sedangkan informan TKI legal berpendidikan relatif lebih tinggi. Perbedaan tersebut berhubungan de- ngan persyaratan pendidikan TKI legal yang memberikan persaratan ijazah minimal setingkat SLTP. Dengan demikian, informan yang berpendidikan rendah telah tereliminasi secara langsung dari persaingan untuk menjadi TKI resmi. Selanjutnya, mereka menempuh jalan lain dan terjebak dalam perangkat pemberangkatan ilegal. Hal ini menguatkan argumen bahwa calo dapat menjembatani bahasa, informasi, dan kesulitan yang dihadapi oleh calon TKI dalam mengurus dokumen pemberangkatan. ${ }^{7}$ Sebaliknya informan berpendidikan lebih tinggi mendapatkan informasi dari institusi resmi. Tingkat pendidikan memungkinkan mereka berfikir lebih jernih untuk mempertimbangkan keuntungan dan kerugian memilih tempat pendaftaran sehingga tidak mudah terjebak oleh calo.

Berdasar data Survey Sosial Ekonomi Nasional tahun 2004, di Propinsi Sumatera Barat, proporsi angkatan kerja dengan pendidikan SLTA ke bawah masih tinggi yaitu tamat Sekolah Dasar (26\%), SLTP (22\%) dan SLTA $(23 \%)$. Proporsi masyarakat berpendidikan rendah yang besar perlu mendapat perhatian serius dari berbagai pihak. ${ }^{14}$ Berdasarkan informasi dari Direktorat Jenderal P2TKLN Departemen Tenaga Kerja dan Transmigrasi RI, Depnakertrans RI telah membuat perjanjian kerja sama dengan Depdiknas RI untuk meningkatkan pendidikan calon TKI melalui program pendidikan setara SLTP (Program Paket B). Hal tersebut diharapkan dapat memberikan peluang lebih besar pada masyarakat berpendidikan rendah untuk menjadi TKI, yang mempersyaratkan pendidikan minimum tamat SLTP.

\section{Kekerasan Pra Berangkat \\ Kekerasan Ekonomi}

Kepentingan, peranan dan kewenangan berbagai komponen yang terlibat yang meliputi TKI, calo, PJTKI, dan pemerintah yang tidak seimbang memperbesar risiko benturan/konflik kepentingan selama masa interaksi. Ekonomi merupakan alasan paling utama bagi TKI untuk meninggalkan Indonesia sebagaik akibat kesulitan mendapat pekerjaan dan penghasilan layak. Teori push factors migrasi menyatakan bahwa dorongan bermigrasi akan muncul ketika migran tidak memperoleh peluang ekonomi yang layak di negara asal mereka. ${ }^{15}$ Dengan tingkat pendidikan yang rendah para pemburu pekerjaan itu lebih sulit bersaing di pasaran tenaga kerja. Motivasi ekonomi tersebut di manfaatkan oleh PJTKI/calo dengan menawarkan gaji besar yang mampu membeli tanah dan membangun rumah yang menggiurkan. Hal tersebut diungkapkan oleh informan PJTKI sebagai strategi promosi menawarkan job order kepada masyarakat.

Temuan ini tidak jauh berbeda dengan hasil studi yang dilakukan terhadap 30 TKW yang mengadukan nasib pada LSM Solidaritas Perempuan pada periode 19941997, menemukan TKW dijadikan pembantu tukang 
batu katika perusahaan membangun gedung. ${ }^{16}$ Penelitian Human Right Watch menemukan PJTKI mempekerjakan calon TKI pada staf PJTKI atau orang lain tanpa menerima upah dengan dalih sebagai bagian program pelatihan. ${ }^{17}$ Kekerasan ekonomi selama proses rekrutment tidak terlepas dari sistem kapitalisme yang dianut oleh PJTKI yang menjadi pelaksana utama pengerahan tenaga kerja ke luar negeri. Untuk mengembangkan bisnis yang menguntungkan, PJTKI menerapkan prinsipprinsip ekonomi yang mengakibatkan calon TKI mengalami berbagai bentuk kekerasan ekonomi.

Hal tersebut jelas bertentangan dengan Perjanjian Internasional (UN Convention) tentang perlindungan hak sosial dan politik TKI (pasal 8 ayat 1) yang mencakup hak bekerja dan berusaha yang harus dihormati dan dilindungi. Setiap orang dinyatakan bebas bergerak sampai lintas negara guna memperjuangkan hak ekonomi dan terbebas dari praktek perbudakan. Pasal tersebut juga menegaskan tidak ada badan apapun yang berhak menjadikan manusia sebagai komoditi yang diperdagangkan. Dari pasal-pasal di atas dinyatakan bahwa segala kepentingan, perlindungan, hak-hak dan keselamatan TKI menjadi kewajiban negara. ${ }^{18}$

\section{Kekerasan Psikologi}

PJTKI sering melakukan penyimpangan dengan cara merekrut calon TKI sebelum ada pesanan tenaga kerja dan menampung calon tenaga kerja Indonesia sebagai stok. Hal tersebut bertujuan untuk mempercepat proses pengiriman segera setelah ada ada permintaan. Akibatnya, calon TKI berada di tempat penampungan lebih lama daripada waktu yang ditetapkan. ${ }^{17}$ Selain itu, menurut informan dari LSM Kopbumi, banyak calon TKI yang tidur berdesak-desakan di penampungan yang tidak layak bagi kesehatan, mereka terlantar karena tidak ada kepastian berangkat. Pada penelitian ini, ditemukan juga tempat penampungan calon TKI yang padat dan berdesakan yang tidak memenuhi persyaratan kesehatan. Kekerasan psikologis pada saat pra pemberangkatan tidak dialami oleh para TKI ilegal. Kemungkinan hal ini disebabkan oleh calo yang umumnya yang telah dikenali atau mempunyai kedekatan sosial dengan calon TKI. Selain itu calo masih menunjukkan sikap positif untuk membujuk CTKI, sehingga tidak ditemui keluhan tentang kata-kata kasar.

\section{Periode di Tempat Kerja}

Berdasarkan penelitian Human Rigth Watch, majikan TKW-Pekerja Rumah Tangga di Malaysia melakukan kecurangan terhadap TKI dengan membayar gaji pada akhir masa kontrak. Hal tersebut dilakukan dengan alasan banyak kasus TKI yang melarikan diri. Para majikan juga berdalih akan menabungkan gaji/mendepositokan gaji TKI-PRT tersebut dalam rekening tabungan tersendiri. TKI yang tidak menerima gaji sepenuhnya sebelum pulang, berpeluang kecil untuk mengklaim gaji setelah tiba di Indonesia. ${ }^{17}$ Padahal, menurut Kovensi ILO tahun 1990, pengusiran buruh migran dari negara tempat mereka bekerja tidak boleh mengurangi hak apapun yang telah diperoleh buruh migran dan keluarganya termasuk hak untuk menerima gaji. Selain itu buruh migran juga berhak atas kesempatan yang layak sebelum atau sesudahnya keberangkatannya untuk menyelesaikan pembayaran gaji atau hutang-hutang mereka. ${ }^{19}$ Penelitian Human Right Watch tentang kekerasan ekonomi pada TKI selama di tempat kerja adalah tidak menerima gaji secara penuh, tidak menerima gaji sama sekali, dan yang berharap masih akan menerima gaji setelah kontrak selesai. ${ }^{17}$

Kekerasan fisik dapat mengakibatkan rasa sakit, jatuh sakit, atau luka berat. Menurut Heise ${ }^{1}$ dampak kekerasan fisik adalah gangguan terhadap kesehatan fisik seperti: trauma/luka fisik, kehamilan yang tidak diinginkan, penyakit menular seksual, keguguran dini, sakit kepala serta gangguan pencernaan. Kekerasan fisik yang berdampak langsung terhadap kondisi fisik terutama terjadi pada informan TKI yang berangkat secara ilegal. Penelitian ini tidak jauh berbeda dengan temuan Human Right Watch yang menerima laporan adanya para pekerja rumah tangga di Malaysia yang mengalami luka-luka akibat pelecehan fisik dan seksual baik pada saat di penampungan maupun di rumah majikan. ${ }^{4}$

Temuan ini tidak jauh berbeda dengan temuan Human Right Watch terhadap TKI pekerja rumah tangga di Malaysia, bahwa meeka bekerja selama 16 jam atau lebih setiap hari. ${ }^{17}$ Hal yang sama juga terjadi pada TKW pekerja rumah tangga di Arab Saudi yang bekerja dengan beban berat dan dalam waktu sangat panjang. ${ }^{20}$ Menurut ILO, jam kerja normal adalah 8 jam/hari. Namun, peraturan Depnakertrans RI menetapkan minimal TKI beristirahat 8 jam sehari, sehingga majikan yang mempekerjakan TKI selama $16 \mathrm{jam} /$ hari belum melakukan pelanggaran. Hal tersebut menguntungkan pihak pengguna dan terkesan tidak melindungi TKI. Hal ini bertentangan dengan hak buruh migran atas kesehatan pada konvensi ILO tahun 1990 yang menyatakan bahwa buruh migran dan anggota keluarganya berhak untuk menerima perawatan kesehatan untuk mempertahankan hidupnya berdasarkan perlakuan yang sama dengan warga negara yang bersangkutan. ${ }^{19}$

Kasus-kasus lain yang tercatat pada dokumen Kopbumi adalah TKI dipaksa memakan makanan yang diharamkan oleh agamanya. Mereka juga mengalami penyiksaan seerti dipukul dengan tongkat besi, diseterika, kemaluannya ditusuk pakai besi atau kayu, disuruh tidur di lantai tanpa peralatan tidur yang memadai, dll.

Kekerasan psikologis dapat mengakibatkan ketakutan, hilang rasa percaya diri, hilang kemampuan bertin- 
dak dan rasa tidak berdaya atau penderitaan psikis berat. Harga diri merupakan penilaian kemampuan, keberartian dan keberhasilan diri sendiri yang diekspresikan melalui berbagai sikap. Orang yang rendah diri cenderung merasa takut melakukan hubungan sosial dengan orang lain, sehingga menarik diri dari lingkungannya. ${ }^{21}$ Menurut WHO ciri jiwa yang sehat adalah rasa nyaman berhubungan dengan orang lain. Kekecewaan terjadi karena alasan terpenting menjadi TKI adalah mendapatkan penghasilan yang lebih baik daripada di dalam negeri. Kasus pelecehan dan makian terjadi umumnya karena kejengkelan majikan ketika informan TKI tidak dapat mencapai target pekerjaan. Hal ini mungkin berhubungan dengan keterampilan dan pendidikan TKI yang rendah. Human Right Watch mengatakan bahwa para pekerja umumnya mengalami pelecehan dan kekerasan psikologis karena telah melakukan kelalaian. ${ }^{17}$

Berbeda dengan penelitian ini, dokumen Kopbumi mencatat kasus kekerasan seksual yang dilakukan secara terorganisir. TKW dipaksa menjadi pekerja seksual oleh sindikat perdagangan manusia dengan modus sebagai pekerja seni atau kawin kontrak. Perdagangan manusia terhadap tenaga kerja perempuan Indonesia banyak ditemukan di Malaysia, Jepang, Korea, Taiwan dan Hongkong. ${ }^{22}$ Menurut Human Right Wacth informasi dan perlindungan yang kurang pada proses migrasi tenaga kerja mengakibatkan banyak migran beresiko tinggi mengalami perdagangan manusia dan terjebak dalam situasi kerja paksa karena alasan ekonomi. ${ }^{17}$ Dari perspektif perempuan, ancaman perkosaan dan kasus pelecehan seksual, merefleksikan kondisi kehidupan seks yang tidak lagi dilakukan secara sakral dalam sebuah lembaga perkawinan. Para TKI wanita itu telah ditempatkan pada posisi yang tidak berdaya sebagai objek seksual bagi laki-laki.

\section{Periode Pulang}

Menurut Lembaga HAM Malaysia (SUHAKAM), korban perdagangan asal Indonesia juga bisa ditemukan di rumah tangga dan bentuk-bentuk kerja paksa lain, seperti kerja paksa seks dan perkawinan paksa. Korban perdagangan manusia tersebut tidak dapat berharapan menerima perlindungan dan bantuan dari pemerintah Indonesia ataupun Malaysia. Mereka mungkin akan didenda, ditahan, dan dideportasi tanpa akses bantuan apapun. ${ }^{23}$

Terminal III Bandara Sukarno Hatta pada mulanya dirancang sebagai tempat terminal khusus TKI yang bertujuan melindungi TKI ketika pulang. Akan tetapi banyak laporan dan berita tentang pemerasan yang dilakukan oleh petugas terhadap TKI atau keluarga TKI yang menduga TKI memiliki uang tunai dalam jumlah besar. 12

Penahanan paspor TKI bertujuan untuk mempertahankan kendali majikan terhadap TKI dan sebagai jami- nan agar TKI tidak akan melarikan diri. Akan tetapi menurut Kopbumi, hal ini mengakibatkan TKI rentan akibat tidak mempunyai dokumen sehingga diangap ilegal. Misalnya ketika ia terpaksa harus lari karena perlakuan majikan yang tidak manusiawi. ${ }^{22}$ Dari berbagai kasus yang telah diuraikan di atas, ternyata masih banyak kebijakan/peraturan yang hanya bertujuan untuk melindungi kepentingan pengguna, tetapi tidak untuk kepentingan perlindungan TKI.

\section{Kesimpulan}

Semua TKI mengalami beberapa bentuk kekerasan secara berulang. TKI legal mengalami eksploitasi akibat peraturan dan mekanisme penempatan yang belum melindungi hak azasi manusia. Kekerasan dialami pada periode pra pemberangkatan, periode bekerja di luar negeri dan pada saat pemulangan. TKI ilegal menghadapi resiko kekerasan yang berhubungan dengan hak azasi manusia yang lebih besar dan mengalami dampak kekerasan yang lebih berat.

\section{Saran}

Kepada Dinas Tenaga Kerja dan Transmigrasi Propinsi Sumatera Barat disarankan: Membangun kerja sama dengan media massa untuk menyebarkan informasi publik tentang persyaratan, tata cara, tempat pendaftaran, biaya penempatan TKI dan bahaya trafficking. Melakukan promosi dan informasi PJTKI yang seimbang dan benar. Menjaga kualitas pelatihan sesuai ketentuan dan kebutuhan negara tujuan. Memberikan pelayanan secara bermartabat dengan sikap dan perilaku yang menghargai hak azasi manusia. Melakukan pengawasan dan pemantauan berkala dengan membuka jalur komunikasi dengan para TKI di luar negeri dan pihak pengguna. Kepada LSM, disarankan menggalang kekuatan dan kesadaran publik dalam menegakkan Hak Azasi Manusia (HAM). Melakukan advokasi/lobby/mediasi pada pemerintah dan tokoh masyarakat dalam meningkatkan kesadaran mencegah kekerasan. Kepada Depnakertrans, disarankan mencegah pemberangkatan TKI ilegal dengan: meningkatkan pendidikan masyarakat miskin, merealisasikan kerjasama Depdiknas dan Depnakertrans RI untuk Kejar Paket B dan program pendidikan keterampilan hidup (lifeskill) secara gratis kepada penganggur. Menyederhanakan prosedur pendaftaran dengan pelayanan satu atap dan membuat loket khusus pelayanan penempatan TKI Merevisi peraturan/kebijakan dan upaya diplomasi yang memberikan perlindungan Hak Azasi Manusia (HAM) dengan merujuk kesepakatan internasional.

\section{Daftar Pustaka}

1. Heise, L. Violence Againts Women: An integrated, ecological Framework Violence Againts Women, WHO, New York; 1999. 
2. Mann, Jonathan. Health and Human Right. Routledge, New York and London, 1999

3. WHO, A Universal Challenge, World Report on Violence and Health. Geneva, tahun 2002

4. Suryadi, Charles dan Yvonne Suzy Handayani. Kekerasan dalam Rumah Tangga Sebagai Masalah Kesmasy: Antara Kenyataan dan Harapan, dalam: Majalah Kesehatan Perkotaan tahun VI No. 2. tahun 1999

5. Koran Singgalang, Perantau di Malaysia Minta hentikan Pengiriman TKW, 16-4-2006.

6. Molo, Marcelinus, et all, Masalah Tenaga Kerja di Luar Negeri : Prospek dan Tantangannya Bagi Indonesia, Surakarta, 1997

7. Romdiati, Haning. Migrasi TKI dari Indonesia ke Malaysia: Rekrutmen dan Pengelolaan, dalam Majalah Penduduk dan Pembangunan XII (2) tahun 2001

8. Raharto, Aswatini. Indonesia Female Labor Migrants: Experinces Working Overseas ( Case Study Among Returned Migrants In West Java, dalam Journal of Population Vol. 8 No.1, tahun 2002

9. Nasution, A M., Orang Indonesia di Malaysia Menjual Kemiskinan Membangun Identitas, Djogja, tahun 2000.

10. Jurnal Perempuan 26, Kata dan makna: Gender Based Violence, hal 147

11. ILO, Violence at Workplace: an ILO perspective. Seminar Keselamatan dan Kesehatan Kerja, Jakarta. tahun 23-24 Februari 2005

12. Krisnawaty, Tati; Rusdi Tagaroa \& Wahyu Susilo. Feminisasi Buruh
Migran \& Permasalahannya, dalam: Jurnal Perempuan No. 05, tahun 1998

13. Hatmadji, Sri Harijati. Profil Tenaga Kerja Migran Indonesia: Beberapa Karakteristik dan Permasalahannya, dalam: Warta Demografi tahun : 34 No. 1 Tahun 2002.

14. BPPS, SUSENAS 2004

15. Pigay, Natalis. Migrasi Tenaga Kerja Internasional, tahun 2005

16. Tagaroa, Rusdi dan Encop Sofia. Buruh Migran Indonesia Mencari Keadilan. Bekasi.

17. Human Right Watch, Dicari Bantuan : Pelecehan Terhadap PR TMigran Perempuan di Indonesia \& Malaysia diakses 28 Juni 2005 http://www.google.com.id

18. UN Convention, Dokumen Kopbumi, 2005

19. Hak-hak Buruh Migran Menurut ILO Convention, dokumen Kopbumi, tahun 2005.

20. Farida, Anik. Perempuan Buruh Migran di Tengah Kekerasan: Studi tentang Upaya Survival pada Buruh Migran Pekerja Rumah Tangga dalam Menghadapi dan Menyikapi Kekerasan. Prog. Studi Kajian Wanita-UI, Salemba

21. Suminar, Mira. Akibat Kekerasan terhadap 6 orang istri pada aspek fisik, psikologis, sosial dan ekonomi, FKM-UI Depok tahun 2000.

22. Dokumen Kopbumi, Catatan Kondisi Buruh Migran, tahun 2005

23. Komnas HAM, Peta Kekerasan Pengalaman Perempuan Indonesia, Ameepro, Jakarta, 2002 